\title{
Correction to: Prioritization of water erosion-prone sub-watersheds using three ensemble methods in Qareaghaj catchment, Southern Iran
}

Hamid Reza Pourghasemi ${ }^{1}$ • Fatemeh Honarmandnejad ${ }^{1} \cdot$ Mahrooz Rezaei $^{2}$ - Mohammad Hassan Tarazkar ${ }^{3}$. Nitheshnirmal Sadhasivam ${ }^{4}$

Published online: 16 September 2021

(C) Springer-Verlag GmbH Germany, part of Springer Nature 2021

Correction to: Environmental Science and Pollution Research (2021) 28:37894-37917 https://doi.org/10.1007/s11356-021-13300-2

Unfortunately, we encountered typo-error in the equations presented in Table 3 .

The correct Table 3 is provided in this paper.

The online version of the original article can be found at https://oi.org/ 10.1007/s11356-021-13300-2

Hamid Reza Pourghasemi hr.pourghasemi@shirazu.ac.ir

1 Department of Natural Resources and Environmental Engineering, College of Agriculture, Shiraz University, Shiraz, Iran

2 Soil Science Department, School of Agriculture, Shiraz University, Shiraz, Iran

3 Department of Agricultural Economics, College of Agriculture, Shiraz University, Shiraz, Iran

4 Faculty of Geo-Information Science and Earth Observation (ITC), University of Twente, Hengelosestraat 99, 7514

AE Enschede, The Netherlands 


\begin{tabular}{|c|c|c|c|}
\hline Morphometric Parameters & Formula/Definition & Units & References \\
\hline Stream order $(\mathrm{Nu})$ & Hierarchical order & Dimensionless & (Strahler 1952) \\
\hline Stream Length (Lu) & Length of the stream & $\mathrm{km}$ & (Horton 1945) \\
\hline Length of basin (Lb) & Maximum length of basin & $\mathrm{km}$ & (Ongley 1968) \\
\hline Stream frequency $(\mathrm{Fu})$ & $\begin{array}{l}F u=N / A \\
\text { where, } \mathrm{N}=\text { total number of streams, } \\
\mathrm{A}=\text { area of basin }\end{array}$ & $\mathrm{km}^{-2}$ & (Horton 1945) \\
\hline Drainage density (Dd) & $\begin{array}{l}D d=L u / A \\
\text { where, } \mathrm{Lu}=\text { total length of stream in all orders, } \\
\mathrm{A}=\text { area of basin }\end{array}$ & $\mathrm{km} \mathrm{km}^{-2}$ & (Horton 1945) \\
\hline Drainage texture ratio $(\mathrm{Rt})$ & $\begin{array}{l}T=N / P \\
\text { where, } \mathrm{N}=\text { total number of streams, } \\
\mathrm{P}=\text { perimeter of basin. }\end{array}$ & $\mathrm{km}^{-1}$ & (Horton 1945) \\
\hline Constant of channel maintenance (C) & $\begin{array}{l}C=\frac{A}{\sum_{j=m}^{j=1} L u} \\
\text { where, } \mathrm{A}=\text { area of basin, } \mathrm{Lu}=\text { length } \\
\text { of streams in all order }\end{array}$ & $\mathrm{km}$ & (Horton 1945) \\
\hline Form factor (Rf) & $\begin{array}{l}R f=A /(L b)^{2} \\
\text { where, } \mathrm{A}=\text { area of sub-watershed, } \mathrm{Lb}=\text { basin length }\end{array}$ & Dimensionless & (Horton 1945) \\
\hline Shape factor (Bs) & $\begin{array}{l}B s=\frac{L b^{2}}{A} \\
\text { where, } \mathrm{Lb}=\text { basin length, } \mathrm{A}=\text { area of sub-watershed }\end{array}$ & Dimensionless & (Horton 1945) \\
\hline Compactness coefficient $(\mathrm{Cc})$ & $\begin{array}{l}C c=0.28 \times(P / \sqrt{A}) \\
\text { where, } \mathrm{P}=\text { perimeter of sub-watershed, } \\
\quad \mathrm{A}=\text { area of sub-watershed }\end{array}$ & $\mathrm{km}^{-1}$ & (Horton 1932) \\
\hline Elongation ratio $(\mathrm{Re})$ & $\begin{array}{l}\mathrm{Re}=1.128 \frac{\sqrt{A}}{L b} \\
\text { where, } \mathrm{A}=\text { area of sub-watershed, } \mathrm{Lb}=\text { basin length }\end{array}$ & Dimensionless & (Schumm 1956) \\
\hline Basin relief (Bh) & $\begin{array}{l}\text { Vertical distance between the lowest and } \\
\text { highest points of basin. }\end{array}$ & $\mathrm{m}$ & (Horton 1932) \\
\hline Relief ratio (Rh) & $\begin{array}{l}R h=B h / L b \\
\text { where, } \mathrm{Bh}=\text { basin relief, } \mathrm{Lb}=\text { basin length }\end{array}$ & Dimensionless & (Schumm 1956) \\
\hline Ruggedness number (Rn) & $\begin{array}{l}R n=B h * D d \\
\text { where, } \mathrm{Bh}=\text { basin relief in } \mathrm{km}, \\
\mathrm{Dd}=\text { drainage density }\end{array}$ & Dimensionless & (Moore et al. 1991) \\
\hline
\end{tabular}

Acknowledgements The authors would like to acknowledge Dr. Chen and Dr. Nguyen for their letter to the Editor-in-chief, which made us aware of the typo-error.

Author's contribution All authors read and approved the letter.

\section{Declaration}

Ethics approval and consent to participate Not applicable

Consent for publication Not applicable

Competing interests The authors declare that there is no competing interests

\section{References}

Horton RE (1932) Drainage-basin characteristics. Trans Am Geophys Union 13:350. https://doi.org/10.1029/TR013i001p00350
Horton RE (1945) Erosional development of streams and their drainage basins; hydrophysical approach to quantitative morphology. Bull Geol Soc Am 56:275-370. https://doi.org/10.1130/00167606(1945)56[275:EDOSAT]2.0.CO;2

Ongley ED (1968) Towards a precise definition of Drainage Basin Axis. Aust Geogr Stud 6:84-88. https://doi.org/10.1111/j.1467-8470. 1968.tb00179.x

Moore ID, Grayson RB, Ladson AR (1991) Digital terrain modelling: a review of hydrological, geomorphological, and biological applications. Hydrol Process 5:3-30. https://doi.org/10.1002/hyp. 3360050103

Schumm SA (1956) Evolution of drainage systems and slopes in badlands at Perth Amboy, New Jersey. Bull Geol Soc Am 67:597-646

Strahler AN (1952) Hypsometric (area-altitude) analysis of erosional topography. Bull Geol Soc Am 63:1117-1142. https://doi.org/10. 1130/0016-7606(1952)63[1117:HAAOET]2.0.CO;2

Publisher's note Springer Nature remains neutral with regard to jurisdictional claims in published maps and institutional affiliations. 